\title{
Pembuatan Aplikasi Pengembangan Sistem Pengawasan Kepatuhan Berbasis Web Pada Perusahaan Kontraktor Pertambangan
}

\author{
Talitha Almira, Rizal Isnanto, Kurniawan Teguh Martono \\ Program Studi Sistem Komputer Fakultas Teknik Universitas Diponegoro \\ Jalan Prof. Sudharto, Tembalang, Semarang, Indonesia \\ talithamir@gmail.com
}

\begin{abstract}
Abstrak - Perkembangan teknologi informasi yang sangat pesat memungkinkan suatu data atau informasi dapat disimpan dan diperoleh dengan mudah dan cepat. Dari segi ukuran data, juga dapat dilakukan dalam skala yang besar. Bagi perusahaan bisnis, manfaat teknologi informasi ini umumnya di gunakan untuk mencatat, mengolah dan menyajikan data transaksi berdasarkan proses bisnis yang dijalankannya.

Perancangan aplikasi system pengawasan kepatuhan pada penelitian ini bertujuan untuk merancang system pengawasan kepatuhan sebagai sarana untuk mengawasi tingkat kepatuhan perusahaan kontraktor pertambangan terhadap peraturan yang berlaku. Aplikasi ini berbasis web dengan menggunakan bahasa pemrograman $C \#$ dan basisdata SQL Server Local Database. Dalam melakukan penelitian ini, aplikasi dibangun dengan metode pengembangan perangkat lunak Rapid Application Development (RAD). Pengujian yang dilakukan pada aplikasi adalah dengan menggunakan metode whitebox.

Berdasarkan hasil pengujian yang dilakukan pada aplikasi sistem pengawasan kepatuhan berbasis website, aplikasi sudah mampu berjalan dengan cukup baik. Hasil pengujian menunjukkan berbagai fitur yang ada pada aplikasi ini dapat berfungsi sebagaimana mestinya.
\end{abstract}

Kata Kunci : Teknologi Informasi, white box, rapid application development, pengembangan perangkat lunak

\section{PEndahuluan}

$\mathrm{P}$ erkembangan teknologi informasi yang sangat pesat memungkinkan suatu data atau informasi dapat disimpan dan diperoleh dengan mudah dan cepat. Dari segi ukuran data, juga dapat dilakukan dalam skala yang besar. Bagi perusahaan bisnis, manfaat teknologi informasi ini umumnya di gunakan untuk mencatat, mengolah dan menyajikan data transaksi berdasarkan proses bisnis yang dijalankannya. Dengan didukung oleh teknologi nirkabel, bahkan review atas dokumen transaksi suatu perusahaan dapat dilakukan dengan tidak mengenal jarak dan waktu. Transaksi yang dilakukan di suatu area di Indonesia misalnya, pada saat yang sama sudah dapat dilihat di daerah lain, diseluruh dunia.
Pada suatu perusahaan, pencatatan data atau informasi diperlukan sebagai sebuah dokumentasi, yang akan ditindaklanjuti jika diperlukan. Dalam hal ini tentu saja adalah kejadian-kejadian penting yang berisiko merugikan bagi perusahaan, seperti terjadinya kesalahan angkutan, kekurangan/kelebihan stok barang dan lain sebagainya, yang dapat menyebabkan kerugian bagi perusahaan tersebut maupun konsumennya.

Dalam pembuatan tugas akhir ini pembahasan masalah memiliki batasan pada permasalahan berikut :

1. Sistem berupa aplikasi berbasis web yang diakses pengguna dengan web browser Internet Explorer dan Mozilla Firefox.

2. Kode perangkat lunak ditulis menggunakan bahasa pemrograman C\# dengan kerangka kerja ASP.NET MVC.

3. Basis data dijalankan dengan SQL Server.

4. Lingkup kerja sistem adalah PT. Pamapersada Nusantara sebagai perusahaan kontraktor pertambangan, khususnya jobsite BHPL.

5. Pengguna yang berinteraksi langsung dengan aplikasi sistem pengawasan kepatuhan dibatasi sebanyak 3 aktor diantaranya Admin, Compliance Officer, Manager. Adapun pengguna yang tidak berinteraksi langsung dengan aplikasi diantaranya HCGS Dept Head Site, BHP Compliance, Related Parties bertugas seperti yang digambarkan pada bisnis proses Gambar 2.

\section{LANDASAN TEORI}

A. Penelitian Terdahulu

Dalam melakukan penelitian mengenai pembuatan aplikasi pengembangan sistem pengawasan kepatuhan berbasis web pada perusahaan kontraktor pertambangan mengambil beberapa referensi berupa dokumentasi dari sistem Corporate Tax Online Report.

PT. Pamapersada Nusantara (PAMA) selaku kontraktor pertambangan telah memiliki beberapa aplikasi report service diantaranya adalah Corporate Tax Online Report. Aplikasi tersebut digunakan untuk mencatat laporan tax secara online berbasis web.

Perbedaan dengan penelitian yang akan dilakukan oleh penulis adalah pembuatan aplikasi sistem pengawasan kepatuhan dibuat berdasarkan komitmen anti-korupsi PAMA dan mitra kerja. Aplikasi ini memiliki beberapa fitur utama 
yaitu mencatat laporan, mencetak laporan, dan melihat ringkasan data laporan. Adapun persentase tingkat kepatuhan yang ditampilkan dalam bentuk grafik. Penelitian ini menggunakan metodologi pengembangan perangkat lunak Rapid Application Development (RAD) dengan kerangka kerja ASP.NET MVC.

\section{B. ASP.NET MVC}

ASP.NET MVC adalah kerangka kerja pengembangan Web dari Microsoft yang menggunakan arsitektur MVC. ASP.NET MVC merupakan ide dan teknik paling terbaru dalam pengembangan Agile dan merupakan kerangka kerja terbaik dari platform ASP.NET. Kerangka kerja ini merupakan alternatif lengkap sebagai pengganti ASP.NET Web Forms ${ }^{[1]}$. Microsoft menyediakan ASP.NET yang matang, komponen dan fasilitas yang terbukti untuk mengembangkan aplikasi web yang efektif dan efisien. ASP.NET MVC berdasarkan platform .NET yang memiliki fleksibilitas untuk menulis kode didalam semua bahasa .NET dan mengakses fitur API. Fiturfitur platform ASP.NET yang siap pakai seperti otentikasi, keanggotaan, peran, profil, dan internasionalisasi dapat mengurangi sejumlah kode yang dibutuhkan untuk mengembangkan dan memelihara aplikasi web, dan fitur ini hanya efektif bila digunakan dalam kerangka MVC. ${ }^{[2]}$

\section{Entity Framework}

Entity framework merupakan sekumpulan teknologi ADO.NET yang membantu memetakan antara pengembangan object-oriented dan basis data ${ }^{[9]}$. Terdapat tiga cara untuk bekerja dengan entity framework, diantaranya adalah: Database First, Model First dan Code First.

\section{SQL Server}

Microsoft SQL Server 2008 R2 adalah generasi berikutnya dari platform Microsoft, dengan fitur baru yang memberikan kinerja yang lebih cepat, dan memberikan wawasan bisnis yang kuat. Microsoft SQL Server 2008 R2 telah membuat dampak pada organisasi di seluruh dunia dengan kemampuan inovatif, peningkatan efisiensi serta kolaborasi antara database administrator (DBA) dan pengembang aplikasi, dan skala untuk mengakomodasi beban kerja data.

\section{E. Visual Studio}

Visual Studio adalah Integrated Development Environment (IDE) dari Microsoft yang digunakan untuk membuat, menjalankan, dan memperbaiki program(aplikasi). Visual Studio dapat digunakan untuk membuat aplikasi dengan berbagai bahasa yang didukung .NET seperti $\mathrm{C}++, \mathrm{C \#}$ dan Visual Basic. IDE ini sangat kuat dan memiliki tool yang canggih untuk membuat aplikasi bisnis. Visual Studio juga mendukung XML/XSLT,HTML/XHTML,Javascript dan CSS. Visual Studio yang terbaru adalah Visual Studio 2013. ${ }^{[4]}$
III. PERANCANGAN SISTEM
A. Tahap Pengembangan Sistem
Perancangan sistem dalam penelitian ini akan menggunakan metodologi pengembangan perangkat lunak Rapid Application Development (RAD). Bab ini akan membahas langkah-langkah perancangan aplikasi satu per satu sesuai dengan tahapan yang ada pada Rapid Application Development. Pada Gambar 3.1 ditunjukkan bahwa RAD memiliki tiga tahapan utama, yaitu Rencana Kebutuhan (Requirement Planning), Proses Desain (Design Workshop), dan Implementasi (Implementation). Sedangkan pada tahap Proses Desain dibagi lagi menjadi dua hal yaitu Desain Sistem (Design System) dan Membangun Sistem (Build System).

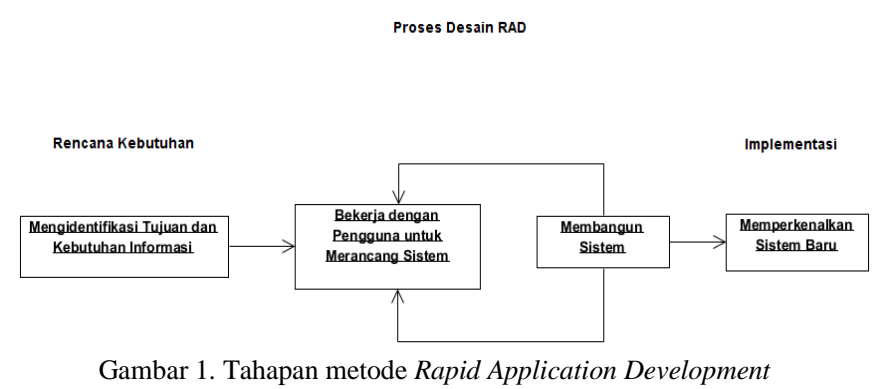

\section{B. Rencana Kebutuhan (Requirement Planning)}

Rencana kebutuhan merupakan tahapan awal dan penting karena pada tahap ini dilakukan perencanaan terhadap sistem, tujuan pembuatan sistem, fungsi-fungsi yang diinginkan serta pengelompokkan terhadap fitur-fitur yang harus ada dan fiturfitur tambahan.

Aplikasi sistem pengawasan kepatuhan ini berfungsi untuk mencatat laporan untuk memastikan semua kegiatan tercatat secara realtime. Secara umum aplikasi ini memiliki berberapa komponen penting, yaitu pencatatan laporan, dan penyimpanan laporan ke dalam basisdata.

Sasaran pengguna aplikasi ini adalah PT. Pamapersada Nusantara khususnya compliance officer dan manager. Sasaran lain dari aplikasi ini adalah memudahkan pengguna dalam pencatatan dan laporan kepatuhan secara online.

Dari perencanaan kebutuhan tersebut dapat digambarkan secara umum sistem yang akan dibuat dengan menggunakan UML, UML yang digunakan adalah UML versi 1.1 dimana terdapat delapan diagram (Use Case, Activity, Sequence, Collaboration, Class, Statechart, Component, Deployment) yang memiliki fungsi-fungsi yang berbeda dalam menggambarkan suatu sistem. Dalam menggambarkan kebutuhan sistem digunakan Use Case Diagram, untuk kebutuhan dari aplikasi ini dapat dilihat pada Gambar 2. 


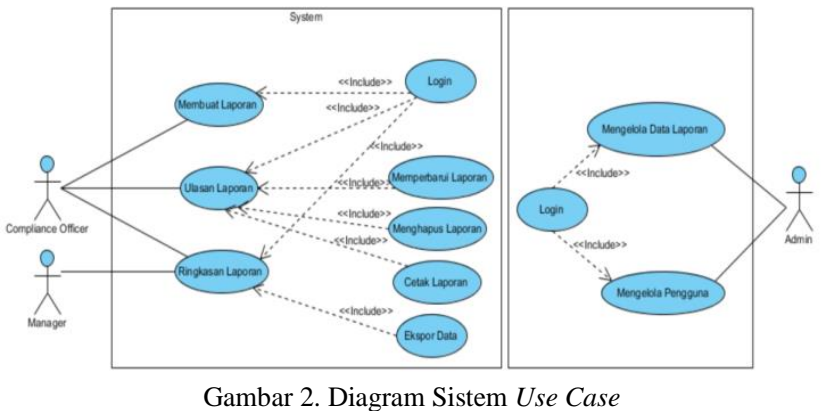

\section{Proses Desain}

Proses desain merupakan proses yang dilakukan setelah perencanaan kebutuhan dilakukan, ini dikarenakan dalam melakukan desain terhadap suatu sistem pasti seorang analis harus mengetahui spesifikasi atau kebutuhan dari sistem itu sendiri. Dalam melakukan desain sistem terdapat beberapa hal yang harus dibuat antara lain desain proses kerja (bussiness process), desain penyebaran sistem (Deployment Design), desain basisdata (Database Design), serta desain tampilan (Layout Design).

Desain proses kerja merupakan desain mendasar mengenai perilaku sistem dan aktivitas yang terjadi ketika aplikasi dijalankan. Aktivitas serta perilaku aplikasi ini digambarkan dalam beberapa Aktivitas Diagram.

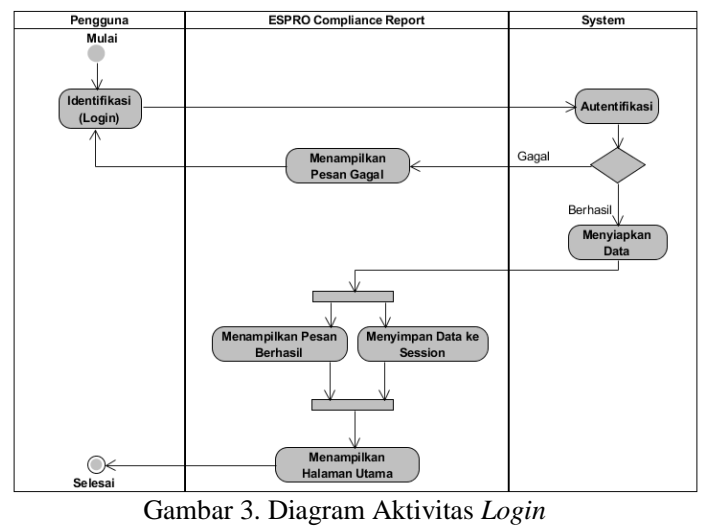

Diagram Aktivitas Login yang terdapat pada Gambar 3. menggambarkan tentang bagaimana proses yang terjadi ketika seorang pengguna masuk ke dalam aplikasi ini.

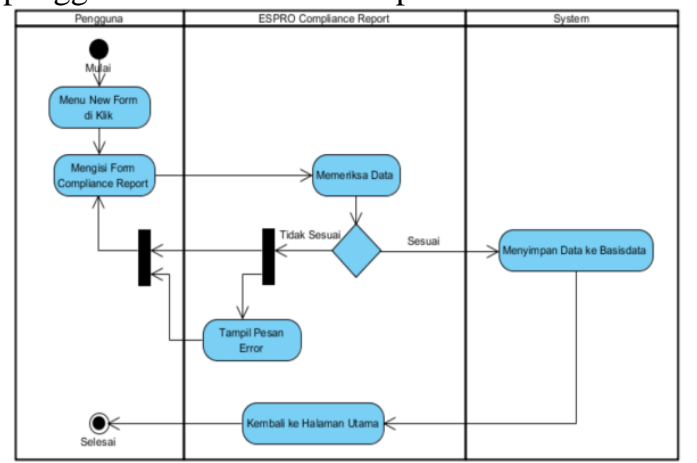

Gambar 4. Diagram Aktivitas Membuat Laporan
Pada Gambar 4. digambarkan bagaimana proses pengguna melakukan pencatatan laporan.

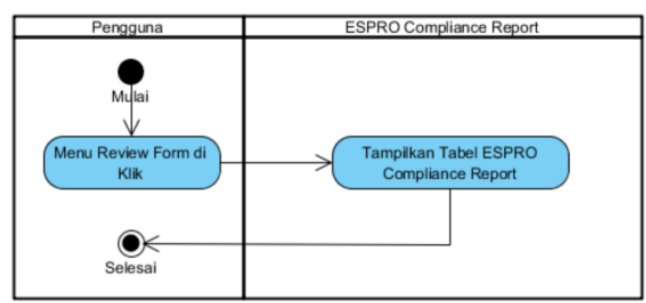

Gambar 5. Diagram Aktivitas Ulasan Laporan

Pada Gambar 5. digambarkan bagaimana proses pengguna melakukan ulasan laporan.

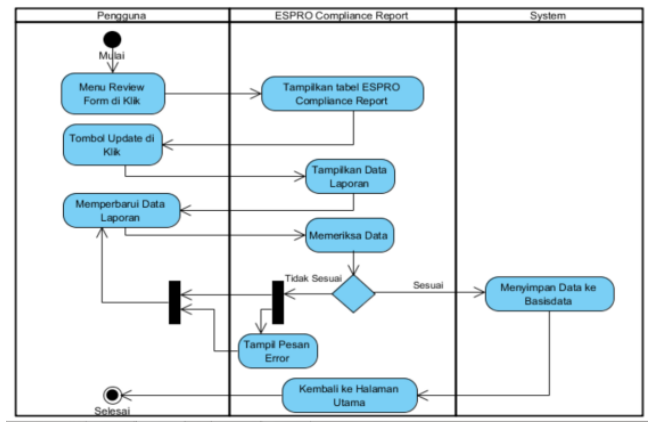

Gambar 6. Diagram Aktivitas Memperbarui Laporan

Pada Gambar 6. digambarkan bagaimana proses pengguna memperbarui laporan.

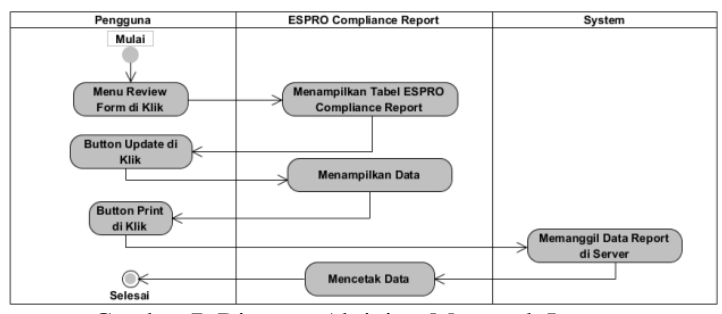

Gambar 7. Diagram Aktivitas Mencetak Laporan

Pada Gambar 7. digambarkan bagaimana proses pengguna mencetak laporan dimulai dari pengguna menekan menu Review Form kemudian aplikasi akan mengarahkan pengguna ke halaman Review Form.

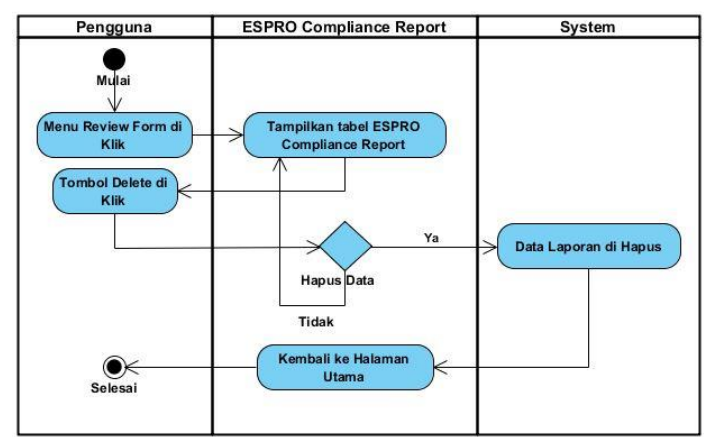

Gambar 8. Diagram Aktivitas Menghapus Laporan

Pada Gambar 8. digambarkan bagaimana proses pengguna menghapus data laporan. 


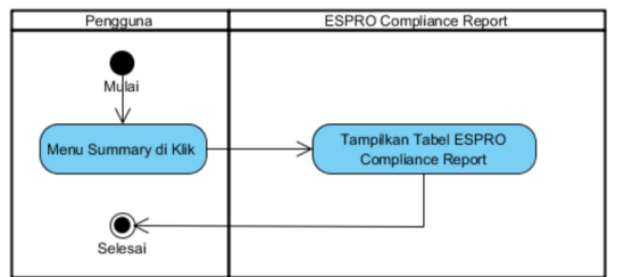

Gambar 9. Diagram Aktivitas Ringkasan Laporan

Diagram Aktivitas Ringkasan Laporan yang terdapat pada Gambar 9. menggambarkan tentang bagaimana proses yang terjadi ketika mengakses ringkasan laporan.

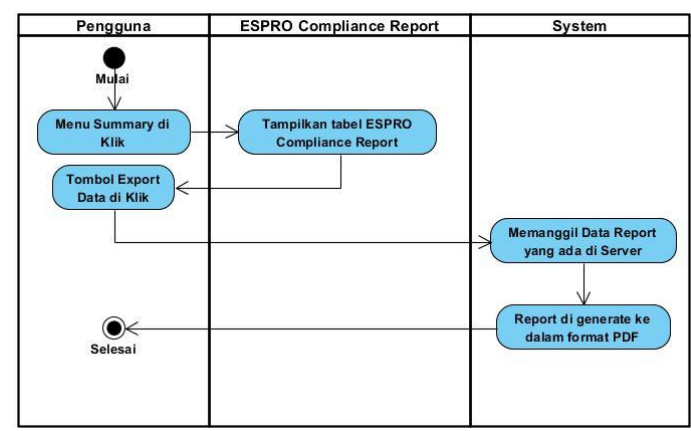

Gambar 10. Diagram Aktivitas Ekspor Data

Pada Gambar 10. digambarkan bagaimana proses pengguna melakukan ekspor data.

Selanjutnya untuk mendeskripsikan bagaimana entitas dalam sistem berinteraksi akan digambarkan dengan Sequence Diagram. Pada Sequence Diagram akan menggambarkan tiap satu Diagram Sistem Use Case.

Pada Gambar 11. menggambarkan mengenai proses yang terjadi pada saat Membuat Laporan.

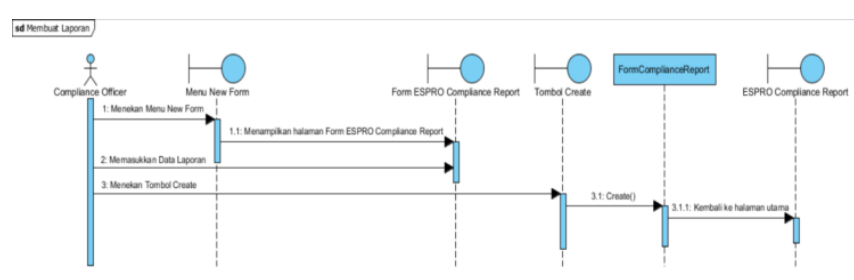

Gambar 11. Diagram Urutan Membuat Laporan

Pada Gambar 12. menggambarkan mengenai proses Ulasan Laporan Laporan.

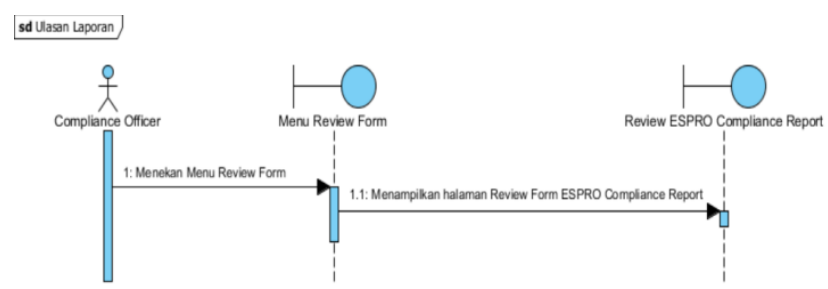

Gambar 12. Diagram Urutan Ulasan Laporan
Pada Gambar 13. menggambarkan Ringkasan Laporan.

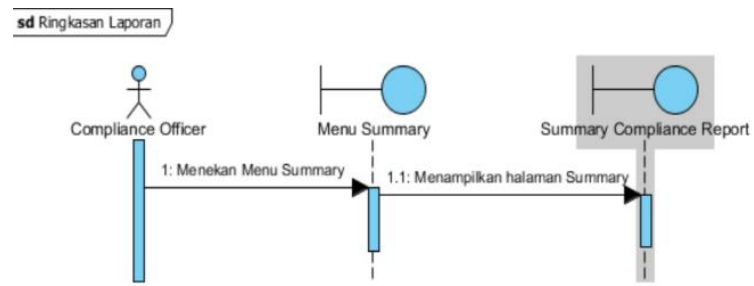

Gambar 13. Diagram Urutan Ringkasan Laporan

Proses berikutnya adalah memperbarui laporan yang digambarkan pada Gambar 14.

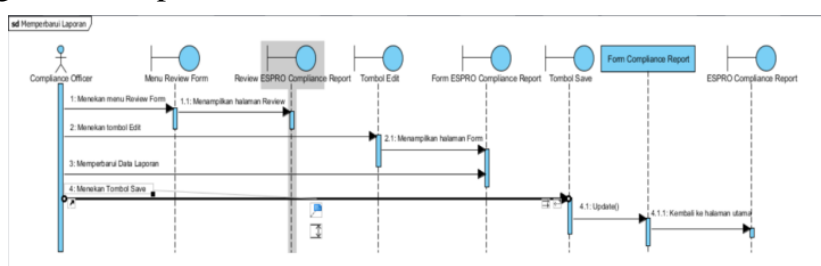

Gambar 14. Diagram Urutan Memperbarui Laporan

Diagram Urutan selanjutnya yaitu menggambarkan proses Menghapus Laporan.

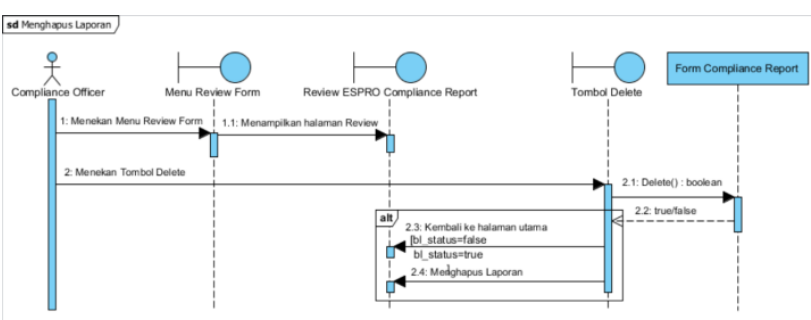

Gambar 15. Diagram Urutan Menghapus Laporan Proses berikutnya adalah Diagram Urutan untuk Cetak Laporan.

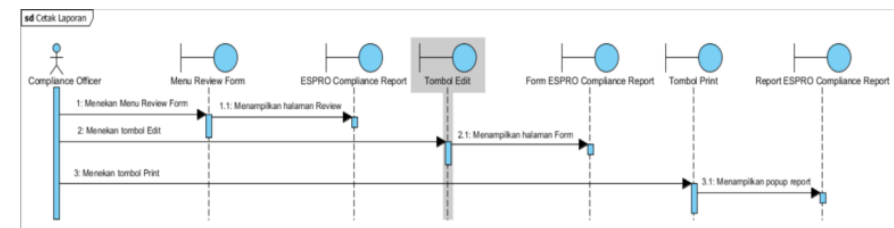

Gambar 16. Diagram Urutan Cetak Laporan

Diagram Urutan untuk proses Ekspor Data digambarkan pada Gambar 17. 


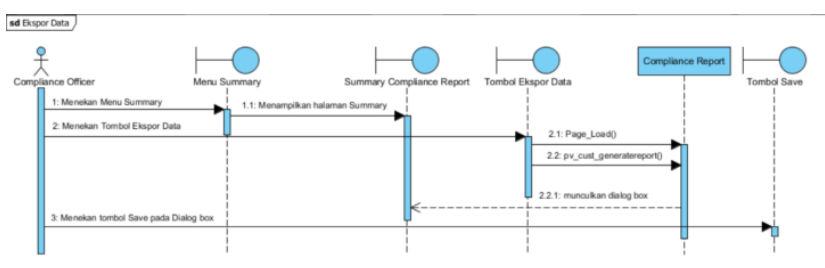

Gambar 17. Diagram Urutan Ekspor Data

Proses selanjutnya pada Diagram Urutan dilakukan oleh aktor Admin digambarkan pada Gambar 18.

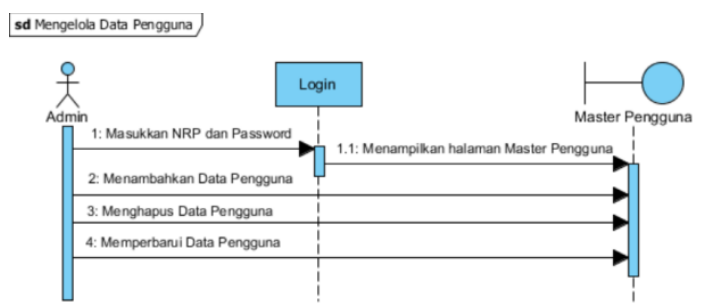

Gambar 18. Diagram Urutan Mengelola Data Pengguna

Pada perancangan perangkat lunak, desain basisdata merupakan suatu tahap yang sangat penting, dimana dalam tahap ini akan dilakukan pembuatan desain dari skema penyimpanan data dari perangkat lunak.

\begin{tabular}{|c|c|c|c|}
\hline \& TBL_M_BHP & 4\% TBL_I_ComplianceReport & of TBL_M_ThirdP... ^ & \& VW_ComplianceReport ^ \\
\hline$=$ Properties & ${ }^{3}$ Properties & $=$ Properties & $\exists$ Properties \\
\hline 甲? PID & Yi PID_ComplianceReport & pi PID & qi PID_ComplianceReport \\
\hline 5 KodeBHP & \& PID_Pama & sodeThirdParty & \& PID_Pama \\
\hline \& NamaBHP & F NoReport & \& NamaThirdParty & qi NoReport \\
\hline $\boldsymbol{N}$ IsSelected & \& LokasiKejadian & IsSelected & L Lokasikejadian \\
\hline$=$ Navigation Properties & S Jeniskejadian & $=$ Navigation Properties & \& Jeniskejadian \\
\hline & Deskripsikejadian & & Deskripsikejadian \\
\hline \& IBL_M_tipePe... ^ & $\begin{array}{l}\text { \& DampakOperasional } \\
\& \text { Statuskejadian }\end{array}$ & \& TBL_M_Jenisk... ^ & $\begin{array}{l}\text { \& DampakOperasional } \\
\& \text { Statuskejadian }\end{array}$ \\
\hline Properties & & Properties & \& Keterangan \\
\hline q NRP & $\begin{array}{l}\text { S TindakLanjut } \\
\& \text { StatusBayar }\end{array}$ & qi PID & $\begin{array}{l}\text { \& Tindakkajuut } \\
\boldsymbol{\varepsilon} \text { StatusBayar }\end{array}$ \\
\hline \& TipePenanggun... & \& Barang & $\&$ KodeKejadian & 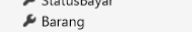 \\
\hline${ }^{a}$ Navigation Properties & \& PIC_PTLC & $\begin{array}{l}\text { \& KeteranganKeja... } \\
\& \text { IsSelected }\end{array}$ & $\&$ PIC_PTLC \\
\hline & $\begin{array}{l}\text { A PIC_Pama } \\
\& \text { UangTunai }\end{array}$ & Navigation Properties & $\begin{array}{l}\text { A. PIC_Pama } \\
\text { \& UangTunai }\end{array}$ \\
\hline भ TBL_M_Lokasi & $\begin{array}{l}\text { S Uang Tunai } \\
\text { Transfer }\end{array}$ & & $\&$ Transfer \\
\hline$=$ Properties & AccountNumber & 4\% TBL_M_NoRep... & AccountNumber \\
\hline p? PID & $\begin{array}{l}\text { Date } \\
\text { \& DueDate }\end{array}$ & & $\begin{array}{l}\text { Date } \\
\text { \& DueDate }\end{array}$ \\
\hline Kodelokasi & $\begin{array}{l}\text { Devare } \\
\mathcal{S} \text { TanggalKejadian }\end{array}$ & = Properties & \& Namalokasi \\
\hline Namalokasi & \& NamaPelapor & qi NoReport & \& TanggalKejadian \\
\hline N IsSelected & F PerusahaanPelapor & Navigation Properties & \& PerusahaanPelapor \\
\hline Navigation Properties & $\approx$ ThirdParty & & $\approx$ KeteranganKejadian \\
\hline \& TBL_M_Users & $\begin{array}{l}\text { S BHP } \\
\text { \& KetKejadianThirdParty }\end{array}$ & \% VW_.gpld & ${ }^{3}$ Navigation Properties \\
\hline & $\begin{array}{l}\& \text { KetKejadianThirdParty } \\
\& \text { TanggalKejadianThirdParty }\end{array}$ & a Properties & \\
\hline Properties & \& NoTelpThirdParty & 4i PID & \\
\hline q? PID & $\&$ KetKejadianBHP & N NRP & \\
\hline$\approx N R P$ & TanggalKejadianBHP & Distrik & \\
\hline Sole & NotelpBHP & $\begin{array}{l}\text { Role } \\
\text { Password }\end{array}$ & \\
\hline Distrik & L LangkahDiambil & Password & \\
\hline$\%$ Password & $\&$ LastUpdate & Navigation Properties & \\
\hline Navigation Prc & Navigation Properties & & \\
\hline
\end{tabular}

Gambar 19. Entity Relationship Diagram (ERD) Aplikasi

Dari desain ERD yang telah dibuat Tabel 1. sampai dengan Tabel 5. menunjukkan kamus data yang akan diterapkan pada basisdata SQL Server seperti berikut.
Tabel 1. Kamus Data TBL_M_NoReport

\begin{tabular}{|l|l|l|}
\hline Kolom & Tipe & Atribut \\
\hline NoReport & Int & $\begin{array}{l}\text { primary key, not null, } \\
\text { unique }\end{array}$ \\
\hline
\end{tabular}

Tabel 2. Kamus Data TBL_M_Users

\begin{tabular}{|l|l|l|}
\hline Kolom & Tipe & Atribut \\
\hline PID & varchar(50) & $\begin{array}{l}\text { primary key, not null, } \\
\text { unique }\end{array}$ \\
\hline NRP & varchar(50) & Not null \\
\hline Roles & varchar(50) & Not null \\
\hline Distrik & varchar(50) & Not null \\
\hline
\end{tabular}

Tabel 3. Kamus Data TBL_M_Lokasi

\begin{tabular}{|l|l|l|}
\hline Kolom & Tipe & Atribut \\
\hline PID & varchar(50) & $\begin{array}{l}\text { primary key, not null, } \\
\text { unique }\end{array}$ \\
\hline KodeLokasi & varchar(10) & not null \\
\hline NamaLokasi & varchar(50) & not null \\
\hline
\end{tabular}

Tabel 4. Kamus Data TBL_M_JenisKejadian

\begin{tabular}{|l|l|l|}
\hline Kolom & Tipe & Atribut \\
\hline PID & varchar(50) & $\begin{array}{l}\text { primary key, not null, } \\
\text { unique }\end{array}$ \\
\hline KodeKejadian & varchar(10) & not null \\
\hline NamaKejadian & varchar(200) & not null \\
\hline
\end{tabular}

Tabel 5. Kamus Data TBL_M_TipePenanggungJawab

\begin{tabular}{|l|l|l|}
\hline Kolom & Tipe & Atribut \\
\hline NRP & varchar(50) & $\begin{array}{l}\text { primary key, not null, } \\
\text { unique }\end{array}$ \\
\hline TipePenanggungJawab & varchar(50) & not null \\
\hline
\end{tabular}


Tabel 5. Kamus Data TBL_T_ComplianceReport

\begin{tabular}{|c|c|c|}
\hline Kolom & Tipe & Atribut \\
\hline PD_ComplianceReport & $\operatorname{varchar}(50)$ & $\begin{array}{l}\text { primary key, not null, } \\
\text { auto increment }\end{array}$ \\
\hline PID_Pama & varchar(10) & not null \\
\hline NoReport & $\operatorname{varchar}(15)$ & not null \\
\hline LokasiKejadian & $\operatorname{varchar}(3)$ & not null \\
\hline JenisKejadian & $\operatorname{varchar}(3)$ & not null \\
\hline DeskripsiKejadian & $\operatorname{varchar}(300)$ & not null \\
\hline LangkahDiambil & $\operatorname{varchar}(10)$ & not null \\
\hline DampakOperasional & $\operatorname{varchar}(300)$ & not null \\
\hline StatusKejadian & $\operatorname{varchar}(5)$ & not null \\
\hline Keterangan & $\operatorname{varchar}(300)$ & not null \\
\hline TindakLanjut & $\operatorname{varchar}(300)$ & not null \\
\hline StatusBayar & $\operatorname{varchar}(10)$ & not null \\
\hline Barang & $\operatorname{varchar}(20)$ & not null \\
\hline PIC_PTLC & $\operatorname{varchar}(20)$ & not null \\
\hline PIC_Pama & $\operatorname{varchar}(20)$ & not null \\
\hline UangTunai & money & not null \\
\hline Transfer & numeric $(18,0)$ & not null \\
\hline DueDate & Datetime & not null \\
\hline TanggalKejadian & Datetime & not null \\
\hline NamaPelapor & $\operatorname{varchar}(20)$ & not null \\
\hline PerusahaanPelapor & varchar(10) & not null \\
\hline ThirdParty & $\operatorname{varchar}(3)$ & not null \\
\hline BHP & $\operatorname{varchar}(3)$ & not null \\
\hline KetKejadianThirdParty & $\operatorname{varchar}(300)$ & not null \\
\hline TanggalKejadianThirdParty & Datetime & not null \\
\hline NoTelpThirdParty & Int & not null \\
\hline KetKejadianBHP & $\operatorname{varchar}(300)$ & not null \\
\hline TanggalKejadianBHP & Datetime & not null \\
\hline NoTelpBHP & Int & not null \\
\hline
\end{tabular}

\section{IMPLEMENTASI DAN PENGUJIAN}

\section{A. Tahap Pembuatan}

Pembangunan aplikasi ESPRO Compliance Report dibagi dalam dua tahap yaitu; tahap pembuatan basis data dan tahap pembuatan aplikasi atau front end.

1. Tahap Pembuatan Basisdata

Pembuatan basisdata dilakukan menggunakan aplikasi SQL Server Management Studio. SQL Server Management Studio menyediakan pembuatan basisdata secara GUI, hanya dengan mengetikkan beberapa hal dan memilih beberapa pilihan saja basisdata dapat dibuat. SQL Server Management Studio juga menyediakan Menu SQL yang dapat digunakan untuk melakukan eksekusi query langsung ke basisdata.
\#TABEL NO REPORT

CREATE TABLE [dbo]. [TBL_M NoReport] (

[NoReport] [int] $\bar{N} O \bar{T}$ NULL

)

Pada kode di atas menunjukkan bagaimana tabel No Report dibuat, tabel ini merupakan tabel master yang kemudian diberi nama TBL_M_NoReport.

\#TABEL LOKASI KEJADIAN

CREATE TABLE [dbo]. [TBL_M_Lokasi](

[KodeLokasi] [varchar] (3) NOT NULL,

[NamaLokasi] [varchar] (50) NOT NULL

)

Kode query di atas digunakan untuk membuat tabel master lokasi kejadian yang diberi nama TBL_M_Lokasi dan bertujuan untuk menampung data lokasi kejadian.

\#TABEL JENIS KEJADIAN

CREATE TABLE [dbo].[TBL_M_JenisKejadian] ( [KodeKejadian] [varchar] (3) NOT

NULL, NOT NULL

[Keterangankejadian] [varchar] (200) )

Tabel master yang ketiga adalah tabel jenis kejadian yang diberi nama TBL_M_JenisKejadian. \#TABEL TIPE PENANGGUNG JAWAB

CREATE TABLE

[dbo]. [TBL M TipePenanggungJawab] ( [NRP] [varchar] (50) NOT NULL,

[TipePenanggungJawab] [varchar] (50) NOT NULL )

Tabel master selanjutnya adalah tabel TBL_M_TipePenanggungJawab yang terdiri dari dua kolom. \#TABEL BHP

CREATE TABLE [dbo]. [TBL M BHP] (

[KodeBHP] [varchar] (3) NOT NULL,

[NamaBHP] [varchar] (50) NOT NULL

)

Tabel BHP dibuat menggunakan kode diatas dengan nama TBL_M_BHP.

\#TABEL ThirdParty

CREATE TABLE [dbo]. [TBL M ThirdParty] ( [KodeThirdParty] [varchar] (3) NOT

NULL,

[NamaThirdParty] [varchar] (50) NOT

NULL

)

Query diatas menunjukkan bagaimana tabel third party dibuat. Tabel ini bertujuan untuk menampung data-data third party.

\#TABEL COMPLIANCE REPORT

CREATE TABLE

[dbo ]. [TBL_T_ComplianceReport] ( [PID_ComplianceReport]

[varchar] $(\overline{5} 0)$ NOT NULL, [PID_Pama] [varchar] (10) NULL, 
[NoReport] [varchar] (15) NOT NULL, [Lokasikejadian] [varchar] (3) NULL, [Jeniskejadian] [varchar] (3) NULL, [Deskripsikejadian] [varchar] (300)

NULL，

[DampakOperasional] [varchar] (300)

NULL,

[Statuskejadian] [varchar] (5) NULL, [Keterangan] [varchar] (300) NULL, [TindakLanjut] [varchar] (300) NULL, [StatusBayar] [varchar] (10) NULL, [Barang] [varchar] (20) NULL, [PIC_PTLC] [varchar] (20) NULL, [PIC_Pama] [varchar] (20) NULL, [UanḡTunai] [money] NULL, [Transfer] [numeric] $(18,0)$ NULL, [AccountNumber] [bigint] NULL,

[Date] [datetime] NULL,

[DueDate] [datetime] NULL,

[TanggalKejadian] [datetime] NULL, [NamaPelapor] [varchar] (20) NULL, [PerusahaanPelapor] [varchar] (10)

NULL,

[ThirdParty] [varchar] (3) NULL, [BHP] [varchar] (3) NULL,

[KetKejadianThirdParty ]

[varchar] (300) NULL,

[TanggalKejadianThirdParty]

[datetime] NULL,

[NoTelpThirdParty] [int] NULL,

[KetKejadianBHP] [varchar] (300)

NULL,

[TanggalKejadianBHP] [datetime]

NULL，

[NoTelpBHP] [int] NULL,

[LangkahDiambil] [varchar] (10)

NULL，

[Lastupdate] [datetime] NULL

)

Pada tabel ini data sistem pengawasan kepatuhan akan disimpan. Kode query diatas digunakan untuk membuat tabel TBL_T_ComplianceReport.

\#VIEW VW ComplianceReport

SELECT - C.PID ComplianceReport, C.PID Pama, C.NoReport, C.Lokasikejadian, C.Jeniskejadian, C.Deskripsikejadian, C.LangkahDiambil, C.DampakOperasional, C.Statuskejadian, C.Keterangan, C.TindakLanjut, C.StatusBayar, C.Barang, C.PIC_PTLC, C.PIC_Pama, C.UangTunai, C.Trañsfer, C.AccōuntNumber, C.Date, C.DueDate, L.NamaLokasi, J.Keterangankejadian, C.Lastupdate, C.TanggalKejadian, C.PerusahaanPelapor FROM dbo.TBL_T_ComplianceReport AS C.INNER JOIN
dbo.TBL_M Lokasi AS L ON C.LokasiKejadian $=$ L.KodeLokasi INNER JOIN dbo.TBL M JenisKejadian AS J ON C.JenisKejāìan = J.KodeKejadian

Penggabungan tabel-tabel baik tabel sebenarnya maupun virtual dilakukan dengan penggunaan fungsi JOIN, pada MySQL fungsi ini dibagi lagi menjadi tiga fungsi LEFT JOIN, RIGHT JOIN, serta INNER JOIN. LEFT JOIN digunakan untuk menggabungkan tabel dengan mengacu pada kunci tabel kiri, RIGHT JOIN digunakan untuk menggabungkan tabel dengan mengacu kunci pada tabel kanan, sedangkan INNER JOIN digunakan untuk menggabungkan tabel dengan mengacu pada kunci kedua tabel yang sama. $O N$ digunakan untuk mewakili karakteristik kunci yang diberikan, jika $O N T R U E$ maka kedua tabel akan digabungkan untuk semua nilai yang ada.

2. Tahap Pembuatan Aplikasi

Pembuatan aplikasi yang dilakukan pertama kali adalah membuat halaman login, halaman ini merupakan halaman yang akan diakses pertama kali oleh pengguna ketika membuka aplikasi, pada halaman ini terdapat dua field yaitu field NRP dan Kata Sandi yang berfungsi untuk menerima masukkan dari pengguna. Pada Gambar 20. merupakan tampilan dari Halaman Login.

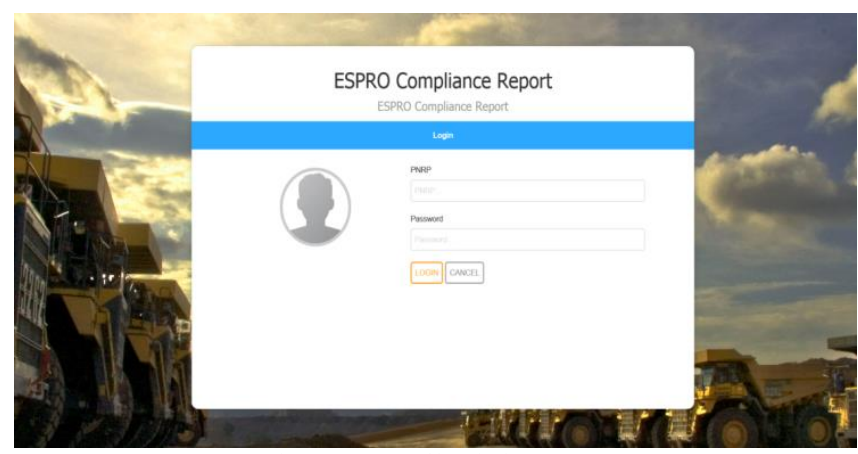

Gambar 20. Tampilan halaman Login

Tahapan berikutnya adalah membuat tampilan halaman utama. Halaman utama terdiri dari navigation bar disebelah kiri dan tabel ESPRO Compliance Report di sebelah kanan. Navigation bar terdiri dari New Form, Review Form, Summary, dan Logout.

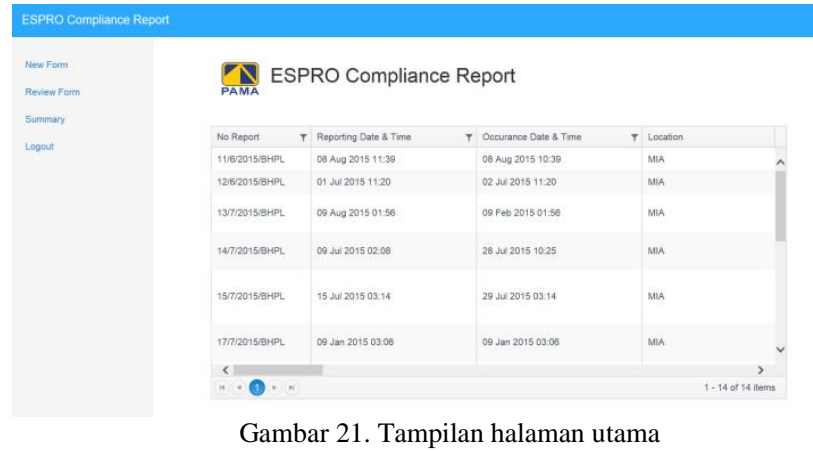


Selanjutnya membuat halaman New Form untuk melakukan pencatatan laporan. Pada halaman ini pengguna akan melakukan pencatatan laporan dan menyimpannya ke basisdata.

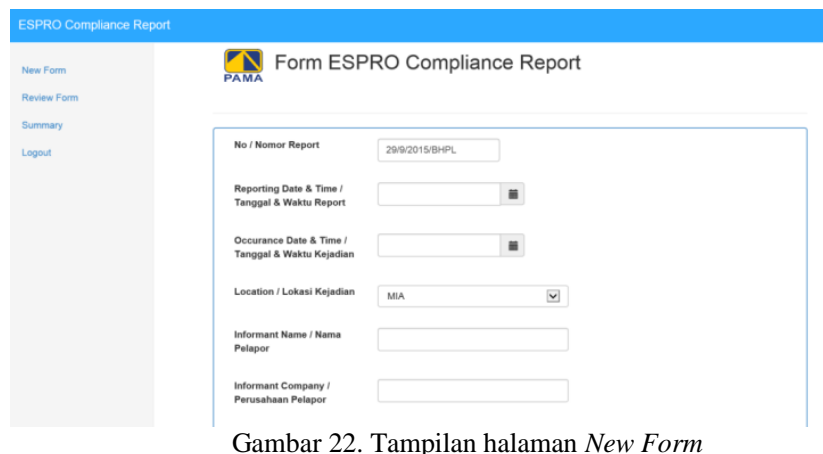

Review Compliance Report berisi tabel data seperti pada halaman utama namun tiap baris disertai dengan button Update. Ketika pengguna menekan button ini maka aplikasi langsung mengarahkan pengguna ke halaman Update Form untuk melakukan pengubahan data. Data otomatis diambil dari basisdata ketika pengguna menekan button Update. Pada halaman ini pengguna juga dapat mencetak laporan yang dapat di generate ke dalam format PDF, Word, dan Excel. Pada Gambar 23 menampilkan halaman Review Form dan Gambar 24 menampilkan halaman Update Form.

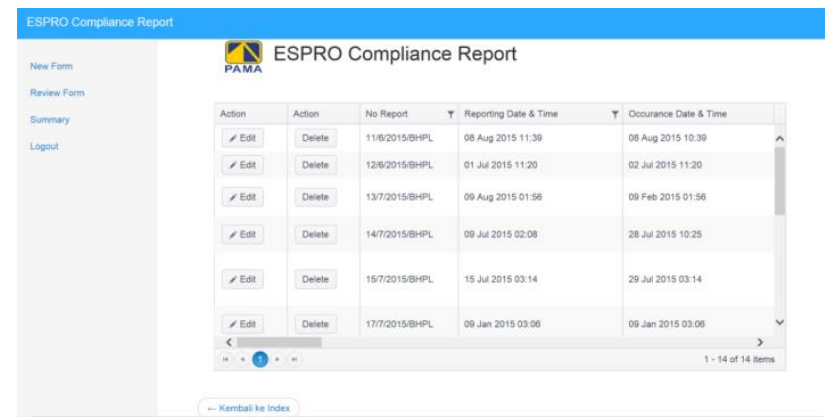

Gambar 23. Tampilan halaman Review Form

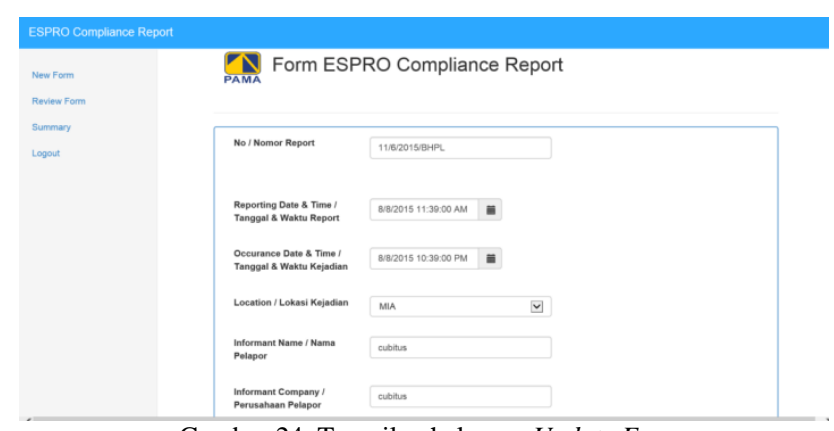

Gambar 24. Tampilan halaman Update Form 


\section{KESIMPULAN}

Kesimpulan dari penelitian tugas akhir ini adalah sebagai berikut:

1. Aplikasi sistem pengawasan kepatuhan berbasis website yang memiliki fitur inti dapat melakukan pencatatan laporan untuk mengawasi tingkat kepatuhan perusahaan kontraktor pertambangan terhadap peraturan yang berlaku.

2. Pengujian yang dilakukan pada aplikasi ini adalah menggunakan metode whitebox dan memperoleh hasil cycolomatic complexity yang diperoleh sudah sesuai dengan tabel jalur proses yang dibuat, sehingga dapat disimpulkan bahwa logika yang diberikan untuk sistem sudah sesuai dengan kebutuhan sistem.

\section{SARAN}

Saran yang diberikan dalam upaya pengembangan sistem yang lebih baik dikemudian hari diantaranya:

1. Aplikasi sistem pengawasan kepatuhan memungkinkan untuk pengembangan aplikasi selanjutnya dalam penambahan fitur-fitur tambahan sesuai dengan kebutuhan pengguna.

2. Perlu dilakukan penelitian lanjutan untuk mengembangkan aplikasi sistem pengawasan kepatuhan menggunakan metode pengembangan perangkat lunak Scrum, yang kemudian dibandingkan dengan metode Rapid Application Development (RAD) untuk dapat diperoleh metode yang terbaik.

\section{DAFTAR PUSTAKA}

[1.] Freeman, A. (2013). Pro ASP.NET MVC 5. New York: Apress.

[2.] M. Zainul, "Thinking Original Entity Framework," 1 July 2011. [Online]. Available: https://zainulmasadi.wordpress.com/2011/07/01/entityframework. [Accessed 12 march 2015].

[3.] M. Ross and M. Stacia, Introducing Microsoft SQL Server 2008 R2, USA: Microsoft Press, 2010

[4.] Moore, A. (2010). Visual Studio 2010 All-in-One Form Dummies. Building (p.916). New Jersey: Wiley Publishing, Inc.

[5.] R. Falzle, Jump Start Bootstrap, (p. 4)

[6.] Aiskahendra, "Perbedaan Razor dan aspx," 17 December 2010. [Online]. Available: https://aiskahendra.wordpress.com/2010/12/17/asp-netmvc-3-mengenal-syntax-razor. [Accessed 12 March 2015].

[7.] Panduan Praktis Menguasai Pemrograman Web dengan Javascript 2009.

[8.] P. Jeffrey and dkk, ASP.NET MVC 4 IN ACTION, Shelter Island.

[9.] Noertjahyana, A., 2002. Studi Analisis Rapid Application Development Sebagai Perangkat Lunal., 3(2), (p.74). 